Beata PAJĄK-PATKOWSKA

Uniwersytet im. Adama Mickiewicza w Poznaniu

Krzysztof PATKOWSKI

Wyższa Szkoła Nauk Humanistycznych i Dziennikarstwa, Poznań

\title{
Węgry w latach 1990-2011. Polityczne, ekonomiczne i społeczne przyczyny kryzysu
}

Wa początku lat 90-tych, gdy Polacy przeżywali szok związany z radykalnymi reformami, Węgrzy cieszyli się z nienajgorzej zaopatrzonych sklepów, relatywnie wysokich pensji i stosunkowo sprawnie, jak na warunki byłych demoludów, funkcjonującej gospodarki. Dwadzieścia kilka lat później Węgry to synonim niekończącego się kryzysu gospodarczego i politycznego, zrezygnowanego i skonfliktowanego społeczeństwa, które w coraz większym stopniu udziela poparcia skrajnym partiom prawicowym. W naszym artykule chcielibyśmy podjąć próbę odpowiedzi na pytanie, dlaczego kraj, do którego wyjazd jeszcze niedawno był marzeniem każdego Polaka, stał się europejskim outsiderem, państwem które znajduje się w sytuacji gospodarczej niewiele lepszej niż Grecja.

Węgry obecnie to kraj pogrążony w głębokim kryzysie gospodarczym. W opinii Organizacji Współpracy Gospodarczej i Rozwoju (OECD) spadek PKB na Węgrzech w tym roku wyniesie 0,6 proc., kraj ten ma również najwyższy w regionie dług publiczny sięgający ok. 80 proc. PKB (w Polsce nie przekracza on 55 proc.). Dwie agencje ratingowe Moody's oraz Standard \& Poor's jeszcze pod koniec 2011 roku obniżyły ocenę wiarygodności Węgier do poziomu „śmieciowego”, argumentując to złą sytuacją gospodarczą i nieprzewidywalną polityką władz. W efekcie od początku 2012 r. możemy obserwować gwałtowne osłabianie się forinta, przy jednoczesnym wzroście oprocentowania węgierskich obligacji. Dziesięcioletnie papiery miały na rynku wtórnym na początku stycznia 2012 rentowność przekraczającą 10 proc., najwyższą od lipca 2009 r. (dla porównania w Polsce to 6 proc.). A im drożej państwo pożycza, tym więcej musi później wydać na obsługę zadłużenia. Niepewność na rynku potęgują też swoimi decyzjami węgierscy politycy, a właściwie jeden, dysponujący nieograniczoną władza, przywódca prawicowego 
Fideszu Viktor Orbán. Premier Węgier nazywany już przez swoich przeciwników „Orbánatorem”, premier porównywany z Hugo Chavezem, premier skonfliktowany z innymi przywódcami europejskimi, czy wreszcie premier wyrzucający z Budapesztu delegacje organizacji międzynarodowych, np. MFW.

Chociaż do 1989 roku gospodarka węgierska jeszcze w małym stopniu odpowiadała definicji rynkowej, to wiele istotnych dla tego typu gospodarki instytucji już istniało. Co ważniejsze, stopień jej otwarcia (mierzony udziałem handlu zagranicznego w PKB) był najwyższy w regionie i nie ustępował rozwiniętym rynkom zachodnim. Inna sprawa, że większość eksportu kierowana była na rynki krajów wchodzących w skład RWPG, a zwłaszcza ZSRR. Węgry posiadały dostęp do międzynarodowych rynków finansowych i cieszyły się na nich stosunkowo dużym zaufaniem. Budapeszt w 1989 roku wydawał się być, w porównaniu z Warszawą czy Pragą, oazą spokoju i dobrobytu, rozwoju przedsiębiorczości, miejscem, gdzie zachodnie firmy mogły inwestować i spodziewać się zysków ${ }^{1}$.

Węgierska droga do demokracji i gospodarki rynkowej do pewnego momentu była najbliższa polskiemu modelowi przeobrażeń. Zarówno historyczna tradycja ruchów narodowo-wyzwoleńczych i powstań narodowych, kultura szlachecka, jak i sposób przetrwania reżimu stalinowskiego upodobniały genezę i uwarunkowania przemian demokratyczno-rynkowych w obu krajach. Jednak już na początku lat 90-tych zarysowały się tu istotne różnice. Na specyfikę węgierskiej drogi i unikanie terapii szokowej, złożyło się wiele elementów ${ }^{2}$ :

1) priorytetem gospodarczym było ciagłe podnoszenie poziomu życia ludności. Ta tendencja była widoczna od lat 70-tych XX wieku. Po zmianie systemu widoczny był wpływ tej polityki na kolejne rządy węgierskie;

2) władze komunistyczne na Węgrzech stworzyły państwo paternalistyczne, ta cecha wiąże się ze wspomnianym wcześniej dążeniem do wzrostu poziomu życia ludności. Udział wydatków socjalnych na Wę-

1 K. Drzyzga, Kryzys gospodarczy na Wegrzech, artykuł opublikowany na http://akson.sgh.waw.pl/kpg/kryzysy z 10.10.03, w ramach badań naukowych „Światowe kryzysy gospodarcze końca XX wieku” prowadzonych przez SGH w Warszawie.

2 A. Wolff-Powęska, Oswojona rewolucja. Europa Środkowo-Wschodnia w procesie demokratyzacji, Poznań 1998, s. 277. 
grzech w PKB był jeszcze do niedawna zbliżony do wartości charakterystycznych dla krajów skandynawskich. Oczywiście inne państwa niedemokratyczne również przywiązywały do tego wagę, ale na Węgrzech wydatki socjalne były szczególnie duże. Dlatego społeczeństwo nie spodziewało się nagłych zmian w gospodarce. Nie spodziewało się spadku dochodów, a wręcz przeciwnie, poprawy sytuacji materialnej;

3) Węgry nie ucierpiały z powodów politycznych od Rewolucji Węgierskiej w 1956 roku. W latach 60-tych i 70-tych polityczne elity w innych krajach niedemokratycznych przeżywały większe lub mniejsze problemy. Z powodu tych turbulencji, zmiana systemu w Polsce, Czechosłowacji czy Rumunii nie przebiegała tak gładko, jak na Węgrzech. Od 1956 roku partia komunistyczna zdecydowała się unikać konfrontacji z opozycją, co sprzyjało powolnym zmianom systemu ${ }^{3}$. Władza, nie dając swobód, starała się jednak dbać o sprawy materialne, zwłaszcza o pełne sklepy. Społeczeństwo pamiętając ofiary 1956 r. nie cisnęło za mocno. Ten rodzaj niepisanej umowy sprawił, że Węgry nigdy nie doświadczyły tak wielu rewolucji gospodarczych jak Polska. Nie było tam budowania „drugich Węgier” z wielkimi, często zupełnie nietrafionymi inwestycjami, ale też nie było stuprocentowych podwyżek cen, tysiącprocentowej inflacji, dorzucania, dla świętego spokoju, pieniędzy najsilniejszym ${ }^{4}$. Po kilku latach terroru związanego z wydarzeniami 1956 roku władza rzuciła hasło „bogaćcie się”. I Węgrzy zaczęli to robić, pracując bardzo często na dwa etaty, jeden w państwowym zakładzie i drugi po godzinach - uprawiali ogrody, działki, zajmowali się chałupnictwem, drobnym rzemiosłem, tworzyli kolektywy pracownicze, które na państwowych maszynach w państwowych fabrykach pracowały po godzinach na własny rachunek. Węgrzy też widzieli ten swój względny dobrobyt i porównując z egzystencją Polaków czy Rumunów doceniali go. Mieli poczucie, że ciężką harówką zapracowali na taki poziom życia ${ }^{5}$;

4) węgierski proces transformacji był stopniowy. Nie zaczął się nagle, wraz ze zmianą systemu politycznego. Reformy zaczęły się w latach 60 -tych i powoli przybliżały początkowo centralnie planowany rynek

3 Ibidem, s. 277-279.

4 D. Zagrodzka, Czy Wegry sq blizej Europy, „Gazeta Wyborcza” z 21.07.1990.

5 Więcej na ten temat w: M. Bechowska, Wegrzy patrza na swoja historie (1945-2003), Warszawa 2004. 
do wolnej konkurencji ${ }^{6}$. Reformy Kadara, mimo wszystkich niekonsekwencji i ograniczeń, były jednak krokiem do przodu, przyswajającym nawyki bardziej rynkowego myślenia przedsiębiorstwom i ludziom stąd przeciętny mieszkaniec Węgier nie przywiązywał dużej wagi do przełomu politycznego, realizowanego w jego mniemaniu już od kilkunastu lat.

W efekcie na węgierską szczególną odmianę reżimu niedemokratycznego składały się reformatorskie działania stanowiące swoistą mieszaninę liberalizmu, paternalistycznego autorytaryzmu i komunistycznego państwa dobrobytu. Oznaczały one wybór liberalizacji, także gospodarczej, zamiast demokracji. Kombinacja rynkowych i nierynkowych elementów w przemyśle, sferze usług i rolnictwie złożyła się m.in. na tzw. drugą gospodarkę. Liberalizacja życia gospodarczego dawała szansę tworzenia prywatnych wspólnot, które mogły wypracować do 20 proc. społecznego produktu brutto. Dzięki reformom węgierskie przedsiębiorstwa mogły prowadzić handel zagraniczny, mogły tworzyć spółki z kapitałem mieszanym. Rodziły się mechanizmy ograniczające subwencje dla towarów i kształtowanie cen na bazie światowych norm, umożliwiające ograniczoną wymienialność forinta, kooperację z EWG, członkostwo w Banku Światowym i generalnie poszerzało otwarcie Weggier na świat ${ }^{7}$. Potwierdzają to również M. Szczepaniak i S. Zyborowicz pisząc, iż: „Dzięki reformom gospodarczym podjętym w 1968 r., mimo ich powolności i ograniczonego zakresu, następowała na Węgrzech stopniowa racjonalizacja nadmiernie upaństwowionej, planistycznie zbiurokratyzowanej i wykluczającej przedsiębiorczość deficytowej gospodarki, powstawały stosunki rynkowe i mechanizmy gospodarcze",

Podkreślała to także T. Surdykowska pisząc, iż: ,,w porównaniu z innymi krajami Europy Wschodniej Węgry były bardziej otwarte na koncepcje gospodarki rynkowej. W momencie rozpoczynania prywatyzacji dysponowały także dobrym wizerunkiem swojego kraju w świecie. Takie elementy, jak stabilizacja polityczna, przeciętna aktywność związków zawodowych i niska inflacja, były brane pod uwagę jako czynniki zmniejszające ryzyko inwestowania na Węgrzech. W tym kontekście

6 The political Economy of Transformation in Post-socialist Hungary, Hungarian Academy of Sciences, Document 39/1996, s. 3.

7 A. Wolff-Powęska, op. cit., s. 279-280.

8 M. Szczepaniak, S. Zyborowicz, Przebudowa ustroju politycznego na Wegrzech $i$ w Czechosłowacji, Poznań 1995, s. 9. 
wysokie zadłużenie tego kraju pozostawało niezauważone. Jeszcze w 1992 r. w badaniach Creditanstalt Węgry były uznawane za najlepsze miejsce do inwestowania w Europie Środkowej i Wschodniej. Jako uzasadnienie podawano ich polityczną i makroekonomiczną stabilność" W podobny sposób postrzegane także przez Polaków. Danuta Zagrodzka pisała w 1990 r.: „Pierwsze uczucie Polaka w Budapeszcie to zazdrość. O niezliczone sklepy i restauracje, eleganckie ulice, dobrze działającą komunikację, o normalność po prostu. Bogu dzięki, telefony działają jak u nas, co trochę zmniejsza frustrację. Frustrujemy się tak na Węgrzech już kilkanaście lat, chociaż przecież nie od zawsze. Warszawa nigdy nie dorównywała Budapesztowi urodą, ale w niektórych dziedzinach mieliśmy kiedyś to przyjemne uczucie lekkiej przewagi, które teraz oni maja wobec nas"10. Jak więc doszło do dzisiejszego załamania?

Przekonanie węgierskiej elity władzy o dużo lepszej sytuacji węgierskiej gospodarki w porównaniu z sąsiadami powodowało, iż kwestie gospodarcze nie były priorytetem pierwszego demokratycznego rządu premiera Josefa Antalla, który skupiał swoją uwagę głównie na kwestiach ideologicznych. W tym okresie duże zainteresowanie inwestorów zagranicznych Węgrami, a także przekonanie, iż to właśnie miejscowi menadżerowie lepiej niż inni zorientowani są w funkcjonowaniu gospodarki rynkowej, sprzyjało konstruowaniu optymistycznych wizji prywatyzacyjnych. Niestety warunki te wyczerpały się już po 2-3 latach i wartość zagranicznych inwestycji zaczęła maleć ${ }^{11}$, a żywot każdego z węgierskich ministrów finansów, który próbował przeforsować bardziej liberalne zmiany, był bardzo krótki. Tak stało się z m.in. z Ferencem Rabárem, który przygotował pierwszy radykalny program reform zakładający liberalizację gospodarki i szybkie dojście do wolnego rynku. Program ten nie uzyskał akceptacji premiera Antalla, a minister, po półrocznym pełnieniu tej funkcji, został zdymisjonowany 20 grudnia 1990 roku. Jego następca, Mihály Kupa, niezrażony niepowodzeniem poprzednika zaproponował program jeszcze bardziej radykalny, w którym

9 T. Surdykowska, Prywatyzacja, Warszawa 1996, s. 175.

10 D. Zagrodzka, Czy Wegrzy sq blizej Europy, „Gazeta Wyborcza” z 21.07.1990.

11 Dominującą rolę Węgier w przyciąganiu zagranicznych inwestorów obrazują dane dotyczące wartości inwestycji za lata 1990 do stycznia 1994 (dane w mld dolarów); Węgry $-5,5$, Polska - 3,04, Czechy - 2,3, Słowacja - 0,13, Dane za J. Perlez, Hungarians cooling to foreign inwestmen, „The New York Times” z 3.05.1994. 
na pierwszym miejscu znalazła się szybka prywatyzacja, a oprócz tego wewnętrzna i zewnętrzna wymienialność waluty, zmniejszenie obciążeń budżetowych w sferze administracji publicznej, reforma systemu podatkowego, dostosowanie prawa do wymogów gospodarki rynkowej. Założenia te zostały ogłoszone 20 stycznia $1991 \mathrm{r}$. Od tego momentu, pierwszy po zmianie systemu na Węgrzech tak całościowy pakiet reform nazywany

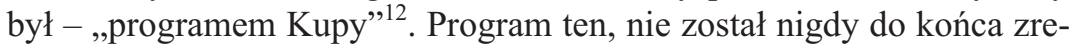
alizowany, a sam jego autor 11 lutego 1993 roku podzielił los swojego poprzednika F. Rabára.

Oceniając cztery lata rządów (1990-1994) koalicji MDF-FKgP-KDNP można wskazać też na kilka elementów, które doprowadziły do jej klęski wyborczej w kolejnych wyborach. W przeciwieństwie do liberalnych: Związku Wolnych Demokratów (SzDSz) i Związku Młodych Demokratów (Fidesz), opowiadających się za terapią szokową na wzór polski, ostrożna koalicja pod wodzą Węgierskiego Forum Demokratycznego (MDF) opowiedziała się za gradualizmem; konserwatyzm ten okazał się bardzo pożyteczny dla stabilizowania sceny politycznej, natomiast katastrofalny w skutkach ekonomicznych (pod koniec 1993 r. produkcja była o 40 proc. niższa niż u progu zmian systemowych) ${ }^{13}$. Dodatkowo, stale trwający spór między premierem a kolejnymi ministrami finansów powodował, że wszystkie odważniejsze projekty reform były torpedowane, przyczyniały się do tego również spory wewnątrz koalicji. W efekcie takie działania rządu doprowadziły do głębokiego kryzysu gospodarczego - pod koniec czteroletniej kadencji PKB zmniejszył się o 20 proc., czemu towarzyszył dynamiczny wzrost bezrobocia. Komentując pierwsze cztery lata węgierskich przemian, w tym zmiany własnościowe, János Kornai, jeden z najwybitniejszych węgierskich ekonomistów, pisał: „Przekroczenie granicy pomiędzy okresami politycznymi nie przyniosło jednak nagłej i dramatycznej zmiany w strukturze instytucjonalnej

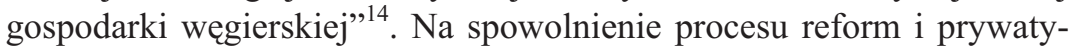
zacji wpływał również zbliżający się termin wyborów parlamentarnych. Wskazuje na to również, K. Drzyzga pisząc: „Rosnące wpływy polityków na gospodarkę przekładały się również na spadek dotychczas niezwykle szybkiego tempa prywatyzacji i restrukturyzacji gospodarki. W latach 1993-1994 nie sprywatyzowano żadnego dużego przedsiębior-

12 B. Góralczyk, Transformacja pokomunistyczna..., op. cit., s. 83.

3 Ibidem, s. 85.

14 B. Góralczyk, Transformacja pokomunistyczna..., op. cit., s. 86. 
stwa, a wyniki finansowe sektora państwowego znacznie się pogorszyły"15. Rząd z lat 1990-1994 pozostawił swym następcom najtrudniejsze decyzje dotyczące reformy budżetu i finansów państwa. Na początku transformacji była w społeczeństwie zgoda co do zmniejszenia roli państwa w gospodarce, szybkiej prywatyzacji przedsiębiorstw państwowych. Po czterech latach opinia publiczna była już mniej chętna do zmniejszenia państwowych wydatków socjalnych, a nie było poparcia dla wprowadzenia konkurencji i sprywatyzowania przedsiębiorstw użyteczności publicznej np. szkół, czy szpitali ${ }^{16}$. W konsekwencji Węgry były kolejnym krajem z byłego bloku sowieckiego, w którym ludzie po kilku latach rządów opozycji zaczynali tęsknić za światem, który wprawdzie wolny nie był, ale dawał poczucie bezpieczeństwa, choć często pozornego, i marnej, ale jednak stabilizacji.

Wbrew oczekiwaniom lata 1994-1998 - okres rządów drugiej, współtworzonej przez niechętnych reformom gospodarczym socjaldemokratów, koalicji na Węgrzech przyniósł zmianę podejścia do gospodarki i przyspieszenie zmian systemowych. W kampanii zapowiadano „gospodarkę rynkową z ludzką twarzą”, troskę o budżetówkę, emerytów, sprawiedliwe rozłożenie kosztów reformy itd. Ogrom koniecznych cięć i restrykcji zaskoczył chyba nawet socjaldemokratycznego premiera Horna, który miał nadzieję, że uda mu się uniknąć bolesnych rozwiązań. Przez ponad pół roku zwlekał z podjęciem jakichkolwiek decyzji, a jeśli je podejmował, to występował w roli hamulcowego.

Pierwszy próbę sprostania trudnym wyzwaniom gospodarczym podjął László Bekesi, będący wówczas drugim po premierze Hornie najważniejszym politykiem Węgierskiej Partii Socjalistycznej (MSZP). Wzorując się na programie Kupy, Bekesi zanegował całą politykę graduzalimu i zaproponował przeprowadzenie reform gospodarczych w oparciu o trzy założenia:

- program transformacji gospodarczej na Węgrzech nie został doprowadzony do końca;

15 K. Drzyzga, Kryzys gospodarczy na Wegrzech, artykuł opublikowany na http://akson.sgh.waw.pl/kpg/kryzysy z 10.10.03, w ramach badań naukowych „Światowe kryzysy gospodarcze końca XX wieku” prowadzony przez SGH w Warszawie.

16 G. Hunya, Frictions in the economic transformation of Czechoslovakia, Hungary and Poland, The Vienna Institute for Comparative Economic Studiem, nr 190, 12.1993, s. 26. 
- nie dokonano przede wszystkim reformy administracji państwowej;

- nadal wysoki pozostaje poziom centralizacji, wpływając na wysokie koszty i rosnacy deficyt ${ }^{17}$.

Program spowodował duże zaniepokojenie wśród współkoalicjantów i sprzeciw samego premiera Horna. W efekcie Bekesi, zaledwie po siedmiu miesiącach sprawowania funkcji ministra finansów, podał się do dymisji w styczniu 1995 r. W takich okolicznościach i wobec szybko pogarszającej się sytuacji gospodarczej ${ }^{18} 1$ marca 1995 r. jego stanowisko przejął Lajos Bokros, który kilka dni później na konferencji prasowej ogłosił swój program reformy finansów państwa, szybko nazwany „programem Bokrosa”. Był to kolejny cios dla zwolenników węgierskiego gradulizmu, gdyż rozwiązania te nawiązywały do najbardziej liberalnych pomysłów Kupy i Bekesiego, a program Bokrosa szybko uznany został za węgierską wersję ,terapii szokowej”. Zawierał on 25 punktów, często bardzo radykalnych cięć i rozwiązań oszczędnościowych, m.in.:

- jednorazową, 9 proc. dewaluację forinta;

- podwyżkę ceł na okres 2 lat;

- cięcia wydatków socjalnych;

- przyspieszenie prywatyzacji.

Był to pierwszy i jak na razie jedyny, tak radykalny, program gospodarczy na Węrzech, który mimo sprzeciwu opozycji i części społeczeństwa, uzyskał akceptację parlamentu i prezydenta Árpáda Göncza. Komentując jego przyjęcie B. Góralczyk pisał: „Dla nikogo zabierającego głos w tej debacie nie było wątpliwości, że wprowadzenie «pakietu Bokrosa» stanowiło istotny zwrot w historii, nie tylko gospodarczej, kraju. Tyle, że wnioski i oceny stąd płynące były inne w różnych środowiskach politycznych i gospodarczych. W ocenie jednych, głównie partii wówczas opozycyjnych, zdecydowano się na zbyt radykalne i liberalne rozwiązania. W ocenie innych, w istocie przedstawicieli rządzącej koalicji, nie było innego rozwiązania, bowiem państwu groził krach

17 L. Keri, w wywiadzie z L. Bekesim, Seria „Portrety polityków”, Budapeszt 1994, w: B. Góralczyk, Wegry..., op. cit., s. 89.

18 Na początku 1995 r. na Węgrzech ujawnił się głęboki kryzys publicznych finansów: deficyt budżetowy odpowiadał 8 proc. wartości produktu krajowego brutto, zaś deficyt bilansu płatniczego 9 proc. W kwietniu 1995 r. analitycy japońskiego banku Nomura prognozowali nawet, że Węgrom grozi kryzys porównywalny z załamaniem się gospodarki meksykańskiej, do którego doszło nieco wcześniej. 
gospodarczy ${ }^{19}$ ". Sam minister, także z powodu cech osobowościowych, stał się wkrótce, podobnie jak L. Balcerowicz w Polsce, najbardziej znienawidzonym węgierskim politykiem. Była to jedna z przyczyn, która wymusiła jego dymisję złożoną 18 lutego 1996 r. Nowym ministrem finansów mianowany został Péter Medgyessy, nie mógł on już jednak powstrzymać zmian wprowadzonych przez poprzednika.

Trudność z wprowadzeniem tak radykalnego programu reform związana była również z napięciami w samej koalicji i partii rządzącej. W partii socjalistycznej uaktywnili się „obrońcy ludu”, protestujący przeciwko programowi stabilizacyjnemu. Grupa ok. 50 posłów z 209-osobowej frakcji socjalistycznej systematycznie dawała premierowi do zrozumienia, że ma dość polityki, w której wyniku popularność rządzących systematycznie spada. Te napięcia w partii stanowiącej filar koalicji rządzącej rzutowały na stosunki socjalistów i samego premiera ze współrządzącymi liberałami. Wzięty w dwa ognie Horn musiał wielokrotnie godzić ogień $z$ wodą ${ }^{20}$.

Bardzo dyskusyjny program gospodarczy stał się wkrótce również katalizatorem podziałów na węgierskiej scenie politycznej, służąc obozowi centroprawicowemu jako wygodne narzędzie do mobilizowania własnych szeregów, a przy okazji pozyskiwania nowych wyborców niezadowolonych z dotkliwych reform. Zwolennicy V. Orbána, oceniając rządy socjalistów, wielokrotnie podkreślali, iż wielu ministrów gabinetu premiera Horna wywodziło się z minionej nomenklatury oraz grup technokratycznych późnego okresu Kadara. W rezultacie „na Węgrzech rządziły komunistyczne kameleony. Cała władza znalazła się w rękach „figur z przeszłości”,21, a „wyeliminowanie ducha konkurencji i współzawodnictwa w społeczeństwie przyczyniło się w dużej mierze do tego, że po utworzeniu w 1994 roku koalicji MSZP-SZDSZ w naszym społeczeństwie nastapił bezprzykładnie szybki upadek moralny i obyczajowy"22. To wszystko wiązać się miało z bogaceniem się nowej postkomunistycznej elity, która profity te miała opierać na swej szczególnej pozycji w państwie partyjnym i jak twierdzili politycy prawicy, „działaniu ka-

19 B. Góralczyk, Wegry..., op. cit., s. 92.

20 W. Maziarski, Po co komu ta koalicja, „Gazeta Wyborcza” z 25.11.1995.

21 B. Góralczyk, Wegry..., op. cit., s. 94.

22 L. Toth, Postkomunistyczna koalicja rzadowa na Wegrzech, w: Janusowe oblicze transformacji na Wegrzech, red. M. Schmidt, L. Gy. Toth, Warszawa 2001, s. 427. 
pitału kontaktów". Oceniając koalicje, MSZP-SZDSZ, L. Toth pisał: „Legitymizacją sprawowania i utrzymania władzy jest «fachowość». W rezultacie ta wolna od ideologii fachowość jest ideologią obu partii. [...] Dzięki ich rządom [koalicji MSZP-SZDSZ, przyp. autora] pozbawionym ideologii, zasad i wartości, państwo znalazło się w trudnej sytuacji. Korupcja stała się jedną z organicznych części systemu [...] niekontrolowana prywatyzacja świadczy o tym, że postkomunistyczne partie lewicowe nie mogą być depozytariuszami przyszłości”23. Taka retoryka przyniosła partiom opozycyjnym zwycięstwo w wyborach 1998 roku. Nowa koalicja, z Fideszem na czele, która doszła do władzy wiosną 1998 r., deklarowała przede wszystkim bardzo wysoki (7 proc.) wzrost PKB, a także reformę systemu zdrowotnego i ubezpieczeniowego. Niewiele z tego wyszło, gdyż jak pisze B. Góralczyk: „Fidesz występując w kampanii wyborczej pod hasłem - więcej niż zmiana rządu, mniej niż zmiana systemu, zaczął zmieniać realia gospodarcze kraju, stawiając na rozwój klasy średniej i własnego kapitału"24. I właśnie to zadanie, wymiana skompromitowanych elit gospodarczych, a nie planowane reformy, stało się najważniejszym punktem programowym nowego rządu. Jednocześnie w ślad za kampanią ideologiczną (siły narodowe kontra liberalne) rozpoczął się bój, w wyniku którego Fidesz zaczął budować własne, alternatywne wobec obozu socjal-liberalnego, zaplecze polityczne o charakterze „,narodowym”, ${ }^{25}$.

Działania trzeciego węgierskiego gabinetu skupiły się wokół takich wartości, jak: naród, rodzina, moralność i praca. W efekcie główne wsparcie ze strony instytucji centralnych otrzymały te podmioty i organizacje, które reprezentowały interesy narodowe lub też interesy Węgrów zamieszkałych za granicą̨. Pakiet tych działań, nastawionych na wartości narodowe, uzyskał nazwę ,programu Széchenyiego”. Jego realizacja przyniosła natychmiastowe ataki opozycji, oskarżającej Fidesz, o centralizację i monopolizację decyzji gospodarczych i procesu prywatyzacji. W efekcie polityka gospodarcza w kadencji parlamentarnej 1998-2002 znalazła się w samym centrum kontrowersji politycznych i była zasadniczą osią podziałów na dwa obozy polityczne opierające się na odmiennych systemach wartości. Dla liberałów i socjalistów punktem

\footnotetext{
23 L. Toth, op. cit., s. 440.

24 B. Góralczyk, Wegry..., op. cit., s. 95.

25 Ibidem, s. 96.

26 Ibidem, s. 102.
} 
odniesienia był pakiet Bokrosa, który w ich opinii przyniósł państwu podstawy trwałego wzrostu gospodarczego i przyspieszenie prywatyzacji. Dla skupionego wokół Fideszu obozu narodowego pakiet Bokrosa stał się swego rodzaju straszakiem przed nadmierną i pospieszną liberalizacją, zbyt wysokimi kosztami społecznymi reform, a także daleko idącym uzależnieniem od „obcych” sił i nie węgierskiego kapitału ${ }^{27}$.

Kolejne wybory w 2002 roku to początek wieloletnich rządów partii socjalistycznej. Mimo, iż wygrał je Fidesz, który uzyskał 188 mandatów przy 41 proc. poparciu, to jednak władzę objęli socjaliści, którzy dzięki koalicji wraz ze Związkiem Wolnych Demokratów mogli utworzyć rząd. Mieli oni łącznie 198 miejsc w parlamencie. Reszta partii nie przekroczyła progu wyborczego. Po wyborach w 2002 roku premierem został Peter Medgyessy, jednak gdy po dwóch latach koalicji rządowej groziło widmo jej rozpadu został zastapiony przez Ferenca Gyurcsánya, który przez kolejne 5 lat stał na czele węgierskiego rządu.

Węgierskie partie jedna po drugiej licytowały się w populistycznych obietnicach. Viktor Orbán w latach 1998-2002 wciąż obiecywał rzeczy wielkie, ale aż do początku kampanii wyborczej trzymał w ryzach państwową kasę. Jego rząd zapoczątkował szereg programów wymagających wielkich nakładów finansowych - np. program budowy autostrad, jednak budżet zaczął się psuć dopiero w lipcu 2001 r. Socjaliści rozpoczynający swe rządy pod silną presją ze strony prawicy mieli nadzieję, że gwałtowny wzrost konsumpcji pozwoli im zdobyć poparcie społeczne. Początkowo Ferenc Gyurcsány starał się rządzić na tyle sprawnie, by nie obciążać budżetu dodatkowymi wydatkami. Jednak jesienią $2005 \mathrm{r}$. wypuścił cugle z rąk i każdy swój krok podporządkował walce z Fideszem $^{28}$.

17 września 2006 r. kilka miesięcy po wygranych wyborach, węgierskie radio ujawniło słynną wypowiedź Gyurcsányego do członków Partii Socjalistycznej, w której premier powiedział prawdę o swoim gabinecie; jego rząd oszukiwał wyborców, kłamał składając nierealne obietnice. Już przed wyborami parlamentarnymi w 2006 r. jasne było, że finanse publiczne są w kryzysie, a gigantyczny deficyt budżetowy nie tylko odsuwa przyjęcie euro, ale też zagraża gospodarce. Mimo to premier licytował się z kandydatem opozycyjnego prawicowego Fideszu V. Orbánem na

27 B. Góralczyk, Węgry..., op. cit., s. 103.

28 P. Toelgyessy, Wegierska katastrofa, „Gazeta Wyborcza” z 30.09.2006. 
obietnice podwyżek emerytur (w odpowiedzi na deklarację wypłaty trzynastej emerytury złożoną przez socjalistów prawica poszła krok dalej, postulując wprowadzenie czternastej emerytury!). W trakcie kampanii w 2006 r. socjaliści uprawiali propagandę sukcesu, nazywając Węgry „pannońską pumą” gospodarczą i wmawiając wszystkim, że są najszybciej rozwijającym się krajem regionu. Mówiono o kraju w przyspieszeniu, a państwowa telewizja pokazywała, jak premier otwiera kolejne odcinki autostrad. Prawdziwe słowa Gyurcsánya o stanie państwa okraszone były potężną dawką przekleństw, wśród których „k...ewski kraj” nie był najbardziej brutalnym, a przemówienie sprawiało wrażenie cynicznego. Ale to nie był cynizm, lecz bluzg człowieka, któremu puściły nerwy, gdy zrozumiał, że jest w ślepej uliczce zaprowadzony tam przez żądzę władzy. Swoją i swojej partii ${ }^{29}$.

Aż do wybuchu kryzysu zadłużeniowego rząd Gyurcsánya koncentrował się na cięciu stawek podatkowych. Robił to z dużą konsekwencją, bez troski jednak o państwową kasę. I tak w szczytowym okresie „dobrobytu” Węgrzy mogli pochwalić się zarówno najniższą stawką podatku VAT (15 proc.) oraz podatku od osób prawnych, będąc najbardziej hojnym wobec obywateli państwem Unii Europejskiej. Państwem, w którym największą pozycję w strukturze wydatków odgrywały nieprzerwanie rosnące transfery socjalne. Szczodrość państwa węgierskiego przejawiała się także w dotowaniu kredytów mieszkaniowych, szerokiej listy farmaceutyków, cen gazu, jak również subsydiowaniu nierentownego transportu miejskiego i kolejowego. Przez ostatnie lata przeciętnemu Węgrowi trudno było zatem dostrzec narastającą nierównowage gospodarczą spowodowaną rosnącym długiem i deficytem finansów publicznych. Sytuacja zmieniła się we wrześniu 2006 r., kiedy to rząd Gyurcsánya powodowany narastającym kryzysem i presją organizacji międzynarodowych wprowadził swój program oszczędnościowy. Był to pierwszy z wielu szok dla budżetów domowych Węgrów. Stało się to za sprawą podwyżek całej gamy podatków i quasi-podatków oraz wzrostu cen gazu, jak i utrzymującym się wysokim kosztom obsługi kredytów walutowych. Cena programu stabilizacji już wtedy wydawała się Węgrom zbyt wysoka. Wbrew pozorom była to jednak cena prawdy, a nie kłamstwa Gyurcsánya ${ }^{30}$.

29 K. Varga, Węierski rokosz przeciw premierowi, „Gazeta Wyborcza” z 20.09.2006.

30 E. Skrok, Wegry placa cenę za rozdawnictwo, „Gazeta Wyborcza” z 25.09.2006. 
W kwietniu 2009 r. premierem Węgier został Gordon Bajnai. Parlament przegłosował tzw. konstruktywne wotum nieufności, pozbawiając władzy Gyurcsánya i wybierając na jego miejsce Bajnaia. Niepopularny Gyurcsány usunął się w cień oficjalnie po to, by umożliwić przeprowadzenie koniecznych reform gospodarczych. Ale jak twierdził opozycyjny Fidesz, były premier, który wskazał Bajnaia na swego następcę, dalej pociagał za sznurki. Nowy premier został szybko okrzyczany przez media „klonem Gyurcsánya”. Choć Bajnai nie był członkiem partii socjalistycznej, to stanął na czele mniejszościowego rządu socjalistów - partii $\mathrm{z}$ rekordowo niskim 10 proc. poparciem społecznym. Premier Bajnai podjął się arcytrudnego zadania. Chcąc skorzystać z 25,1 mld euro pożyczki Międzynarodowego Funduszu Walutowego, musiał ciąć wydatki socjalne, by utrzymać deficyt budżetowy na wymaganym przez Fundusz poziomie 3 proc. PKB. To z kolei oznaczało drastyczne cięcia wydatków socjalnych, co przełożyło się na kolejne spadki notowań socjalistów $^{31}$. Mimo, iż zdaniem wielu niezależnych ekspertów Bajnai $\mathrm{w}$ tej trudnej sytuacji poradził sobie całkiem nieźle i uchronił przed całkowitą zapaścią węgierską gospodarkę, nie mógł jednak powstrzymać wyborczej klęski socjalistów. Do władzy powrócił Fidesz, zdobywając w wyborach 2010 roku absolutną większość w węgierskim parlamencie.

$\mathrm{Na}$ przyczyny sukcesu wyborczego Orbana wskazuje L. Bokros, autor jedynego dotychczas częściowo zrealizowanego programu radykalnych reform. Bokros komentując problemu gospodarcze swojego kraju i jego zapóźnienie nie tylko na tle krajów Europy Zachodniej, ale i Grupy Wyszehradzkiej pisze: „Poważna odpowiedzialność polityczna za taką sytuację obciąża pierwszy rząd Orbána, ale przede wszystkim rządy Medgyessyego i Gyurcsánya. «Fiskalny alkoholizm», nieograniczone kredyty, nadmierne zadłużenie dające w zastaw przyszłość kraju, system edukacji ograniczający młodym pokoleniom możliwości wybicia się, kiepska jakość państwowych usług medycznych, przyjęta $\mathrm{z}$ dumą postawa pasażera na gapę, oszustwa podatkowe uprawiane niczym sport narodowy, zinstytucjonalizowana korupcja wspomagająca finansowanie partii politycznych, aktywny udział przewodniczących szacownych instytucji konstytucyjnych w rozgrywkach politycznych

31 J. Pawlicki, Nowy premier obiecuje, że wyprowadzi Węgry z zapaści, „Gazeta Wyborcza” z 15.04.2009. 
wszystko to przygotowało grunt pod budowę autokratycznego systemu politycznego",32.

Credo swej przyszłej polityki zawarł Orbán w napisanej w 2007 r., w czasie rządów socjalistów książce Ojczyzna jest jedna. Diagnozując sytuację polityczną i gospodarczą swojego kraju stwierdza: „Widzimy słabe Węgry, Ojczyznę wystawioną na sprzedaż”33. Kto chce ją sprzedać? Ci, którym zależy na tym, żeby Węgry były słabe - rząd. Kto chce kupić? Międzynarodowy kapitał, któremu na rękę są Węgry słabe, ubezwłasnowolnione, a także siły niezgadzające się na suwerenność gospodarczą Budapesztu, taką, jakiej domaga się Orbán. A więc jakie mają być silne Węgry? Powinny być samowystarczalne i wyizolowane. W tym miejscu powstaje pytanie czy jest to w ogóle możliwe w przypadku kraju funkcjonującego w realiach światowego handlu i systemu wolnorynkowego. Jak przekonuje lider Fideszu, tak, bo w interesie Węier jest bycie przeciwnikiem światowego handlu i systemu wolnorynkowego, a przynajmniej, jak mówi, „omnipotencji rynku”. Powodem jest tu „,nowa arystokracja" (w domyśle postkomuna, która się uwłaszczyła i z którą Orbán walczy od początku swojej drogi politycznej) znajdująca się u władzy i propagująca dogmat o nadrzędności wolnorynkowej formy gospodarowania. To ona, stojąca ponad prawem, skorumpowana, „dysponująca pieniędzmi napływającymi z Unii bez żadnej kontroli”, jest przyczyną słabości kraju ${ }^{34}$. W efekcie ostatnie 20 lat Węgier jawi się w oczach Orbána jako jedna wielka klęska, której przyczyną były w głównej mierze błędne założenia pakietu Bokrosa. Najlepiej chyba postulaty programowe Orbana skomentował Krzysztof Varga w swoim artykule pod wiele mówiącym tytułem Czas kuglarzy. Varga pisze o książce Orbana: „Ta książka jest zdumiewająca, bo jest ostentacyjnie antymodernizacyjna. Oczywiście, Orbán stoi na czele konserwatywnej partii prosocjalnej (dobrze to znamy z polskich realiów), ale jego antymodernizacyjność, antyrynkowość, uprzedzenia do międzynarodowych firm i kapitału zagranicznego, utopia samowystarczalności gospodarczej kraju, kurs na zamykanie Węgier na świat i tak muszą robić wrażenie"35.

32 L. Bokros, Orban na równi pochyłej (tłum. Justyna Goszczyńska-Prokopowicz), „Gazeta Wyborcza” z 10.03.2011.

33 V. Orbán, Ojczyzna jest jedna, Warszawa 2009, s. 25.

34 K. Varga, We władzy kuglarzy, „Gazeta Wyborcza” z 6.11.2010.

35 Ibidem. 
W ciagu pierwszych ośmiu miesięcy sprawowania władzy Orbán zanegowałł pięć głównych filarów liberalnej demokracji. Przeprowadził zmianę w konstytucji, która ograniczyła kontrolę Trybunału Konstytucyjnego nad działaniami rządu, ograniczył prawa różnych niezależnych organów i instytucji kontrolnych pilnujących rządu. Uderzył w prywatną własność przez nacjonalizację funduszów emerytalnych. Odrzucił pakiet antykryzysowy uzgodniony przez UE oraz MFW, złamał zasadę, że pewne reformy strukturalne podejmuje się w zamian za wsparcie unijne i MFW na czas kryzysu. Złamał też zasadę szczególnego traktowania zagranicznych inwestycji, na których przyciągnięciu do tej pory zależało krajom postkomunistycznym. Nałożył na zagraniczny kapitał - skoncentrowany głównie w bankowości i telekomunikacji - specjalne, przejściowe podatki. Wprowadził też restrykcyjne prawo medialne ${ }^{36}$. Komentując reformatorskie poczynania rządu Fideszu J. Kornai pisał: „Węgierski rząd nie ma spójnego, sensownego programu gospodarczego. Zamiast tego za pomocą dodatkowych podatków, które mocno zniekształcają obraz gospodarki i negatywnie dotykają część podmiotów gospodarczych, próbuje załatać dziury w budżecie, które sam spowodował, i sfinansować zbędne, nieuzasadnione ulgi podatkowe dla bogatych. Przeprowadzona na siłę nacjonalizacja stanowiących ponad 10 proc. PKB środków zgromadzonych w systemie prywatnych funduszy emerytalnych również przyczyniła się do krótkoterminowego załatania budżetu, natomiast na dłuższą metę powoduje jeszcze większe dziury w potężnym worku gospodarki państwowej. Samowolna i karierowiczowska polityka gospodarcza wyjątkowo negatywnie wpływa na oszczędności i inwestycje, na które z punktu widzenia rozkręcenia wzrostu gospodarczego byłoby ogromne zapotrzebowanie" ${ }^{\text {, }}$. Z dzisiejszej perspektywy można powiedzieć, że były to słowa niemalże prorocze. Węgry po ponad roku rządów premiera Orbána ponownie znalazły się w bardzo trudnej sytuacji gospodarczej. Kłopoty węgierskiej gospodarki to nie tylko odprysk kryzysu zadłużenia w strefie euro, ale także wynik niechęci instytucji finansowych do polityki premiera, który na potrzeby permanentnej kampanii wyborczej balansuje na krawędzi, raz negocjując z instytucjami międzynarodowymi, innym razem wyrzucając je z kraju. Chwilowo górą

36 Maciej Stasiński w rozmowie Iwanem Krastewem, Nie chcemy mieć w Unii 27 Orbanów, „Rzeczypospolita” z 15.01.2011.

37 L. Bokros, Orbán na równi pochyłej (tłum. Justyna Goszczyńska-Prokopowicz), „Gazeta Wyborcza” z 10.03.2011. 
są te drugie, obniżając ranking Węgier do poziomu śmieciowego. Czym odpowie Orbán, prawdopodobnie chwilowym złagodzeniem kursu, aby zyskać trochę czasu dla upadającej gospodarki.

Podsumowując, aby znaleźć odpowiedź na pytanie o przyczyny obecnego stanu rzeczy na Węgrzech należy wskazać na:

1. Odwlekane, niedokończone reformy. Paradoksalnie wynikało to ze stosunkowo dobrej sytuacji Węgier u progu zmian systemowych. A wiązało się to $\mathrm{z}$ faktem, iż „Węgrowi było łatwiej idealizować koniec lat 80-tych niż Polakowi. Tutejsi komuniści gospodarowali mądrzej i dzięki temu po upadku poprzedniego systemu krajowi nie była potrzebna terapia szokowa. Węgierska gospodarka, w odróżnieniu od polskiej, nie wymagała reanimacji, a jedynie intensywnego leczenia. W Polsce 1 stycznia 1990 roku był w gospodarce wyrazistą cezurą: skończył się komunizm, zaczęło się to nowe. Na Węgrzech takiej jasnej granicy nie było. Tu nikt nie czekał na «węgierskiego Balcerowicza», do nikogo nie przemawiały zapełniające się półki w sklepach, nikomu nie mogły zaimponować rolki papieru toaletowego piętrzące się w każdym kiosku czy benzyna kupowana bez kartek" "38. Gdy w maju 1990 roku powstawał prawicowy rząd J. Antalla, zaopatrzenie na Węgrzech było przyzwoite. Prawda, że osiagano to poprzez dotacje z budżetu; w 1989 roku pochłonęły one 12\% wartości PKB. Jednak przeciętny klient robiąc zakupy na własne oczy dotacji nie widział. Rząd Antalla, począwszy od 1991 roku wycofywał się z subsydiowania kolejnych działów gospodarki - w 1993 roku na dotacje wydano 4,2\% wartości PKB, trzykrotnie mniej niż w 1989 roku. Stan budżetu państwa nie pozwalał jednak na dalsze subsydiowane gospodarki nawet na takim poziomie, co w efekcie stało się jedną z przyczyn obecnego kryzysu. Węgierski rząd, by przekonać obywateli do swej polityki gospodarczej, musiał, więc posługiwać się danymi makroekonomicznymi i używać argumentów trafiających do ekonomisty, lecz nie do przeciętnego wyborcy ${ }^{39}$. W efekcie żeby nie stracić poparcia tegoż wyborcy podejmował konieczne działania dopiero w sytuacji naprawdę krytycznej. Dlaczego czekano z tym, aż do roku 1995, a nawet wtedy nie doprowadzono reform do końca? Bo to polityka bolesna i niepopularna. Żeby się powiodła, rząd musi mieć mocne poparcie, jak

38 W. Madziarski, Wegry przed wyborem, „Gazeta Wyborcza” z 6.05.1994.
39 Ibidem. 
w początkowym okresie rząd Mazowieckiego-Balcerowicza, albo musi być rządem z charyzmą, jak rząd Vaclava Klausa. Bo choć Klaus nie był nawet wicepremierem, lecz tylko ministrem finansów, to był jego rząd. Na Węgrzech takiego rządu zawsze brakowało ${ }^{40}$.

2. Istnienie dojrzałej sceny politycznej już w początkowym okresie transformacji. Podobnie jak w przypadku opisanych powyżej zmian w sferze gospodarczej, zaawansowanie Węgier w budowaniu nowoczesnego systemu politycznego zamiast pomóc, paradoksalnie utrudniło wprowadzanie niezbędnych reform. Jak wskazuje węgierski ekonomista i polityk SzDSz Tamas Bajer: „Reformy gospodarcze na Wegrzech mogłyby być dużo lepsze, gdyby powstał tu wtedy taki rząd, jak w Polsce, gdzie „Solidarność” tworzyła ramy porozumienia narodowego, czy w Czechosłowacji, gdzie tworzyło je Forum Obywatelskie. To prawda, że węgierska struktura polityczna była najbardziej dojrzała, ukształtował się tu stabilny system wielopartyjny i dojrzały parlament, siły niekomunistyczne podzieliły się na opozycję i rządzących. Tak się nie stało ani w Czechosłowacji, ani w Polsce. Ale Węgry zapłaciły za to bardzo wysoką cenę w sferze ekonomii”" ${ }^{11}$. „Solidarność” i Forum Obywatelskie skupiły wszystkie siły niekomunistyczne i w momencie powstania ich gabinetów miały silną legitymację. Na Węgrzech w 1990 r. taką legitymacją mogłaby dysponować wielka koalicja liberalnego Związku Wolnych Demokratów i prawicowego Węgierskiego Forum Demokratycznego, a do takiej koalicji nie doszło.

3. Wysoki poziom zabezpieczeń socjalnych. J. Kornai nazywa Węgry przedwczesnym państwem dobrobytu, czyli takim, które wykracza poza swój rzeczywisty potencjał gospodarczy. Jak wskazuje Kornai wzrost wydatków socjalnych zaczął się w okresie wzrostu produkcji, ale trwał, kiedy zaczęła się jej stagnacja i spadek. W ten sposób zwiększył się rozziew między potencjałem gospodarczym kraju a zakresem usług socjalnych finansowanych z budżetu. Państwo dobrobytu, które przerosło samo siebie, potrzebuje cięć i reform ${ }^{42}$. W efekcie reforma systemu opieki społecznej była przez lata na Węgrzech tematem tabu. Żaden polityk nie odważył się powiedzieć, że transformacja będzie

40 P. Talas i W. Maziarski w rozmowie z T. Bauerem, Przełom bez gwarancji, „Gazeta Wyborcza” z 18.03.1995.

41 Ibidem.

42 J. Kornai w rozmowie z L. Szabo, Przedwczesne państwo dobrobytu, „Gazeta Wyborcza” z 16.12.1995. 
miała swoich przegranych i nic na to nie poradzimy. Wyjątkiem był tu tylko L. Bokros, szybko zdymisjonowany przez premiera Horna. Laszlo Lengyel, były dyrektor niezależnego Instytutu Badań Finansowych w Budapeszcie, opisując styl uprawniania polityki na Węgrzech pisał w 2003 roku: ,Musimy wygrać wybory - więc obiecujemy i rozdajemy. Do trwającej już wojny ideologicznej dołączył się narodowy oraz socjalny populizm. Każdy, kto znał węgierskie realia, wiedział, że procesy rozdawnictwa po $2001 \mathrm{r}$. są sprzeczne z procesami modernizacji i europeizacji kraju. Obok budowy klienteli celem stało się «zdobycie» jak najszerszego elektoratu. Taka sprzeczna z celami modernizacyjnymi polityka nadmiernego rozdawnictwa trwała przez dwa i pół roku, najpierw pod wodzą młodego i dynamicznego V. Orbana, a potem doświadczonego i rozważnego P. Medgyessyego. Lewica przejęła rządowe pomysły prawicy"43. I jakby przewidując co stanie się 10 lat później Lengyel pisał dalej: „Politycy znowu przekonali ludzi, że wystarczy prosić, żądać, szantażować, a państwo podniesie płace czy wypłaci świadczenia. Na usprawiedliwienie Medgyessyego możemy powiedzieć, że prawica w ten sposób finansowała społeczne podziały, lewica natomiast - pojednanie. Efekt jest ten sam: poprzednio szukano mięsa pod narodowym sosem, a teraz szuka się smacznych kąsków pod sosem różowym. Ale co się stanie, jeśli przetrącimy grzbiet naszej zdolności do konkurencji, jeśli przeputamy i przejemy przyszłość?",4

4. Determinujący wpływ historii na kondycję i nastroje społeczne. Sporo ludzi uważało, że zmiana ustroju przyniesie Węgrom skok modernizacyjny. Że Węgry w ciągu paru lat dogonią Austrię. To nie nastąpiło. Gorzej, Węgry wpadły w kryzys. Mechanizm przerzucania odpowiedzialności na innych pomaga powiedzieć, że odpowiadają za to cudzoziemcy, Żydzi albo Cyganie. Decyzje odwlekano, terapii szokowej nie było. Potem, gdy pojawiły się pierwsze pozytywne rezultaty transformacji, socjalliberalny rząd zaczął to bez opamiętania rozdawać, co wywołało obecny kryzys ${ }^{45}$. Gdy Węgrzy uświadomili sobie, że mają do czynienia nie tylko z kryzysem klasy politycznej, parlamentaryzmu, a więc i demokracji, ale też głęboką zapaścią gospodarczą, popadli

43 L. Lengyel, Czas twardej demokracji, „Gazeta Wyborcza” z 30.10.2003.

44 Ibidem.

45 J. Celichowski w rozmowie J. M. Rainerem, Niezamknięta historia, „Gazeta Wyborcza” z 10.04.2010. 
w depresję. Rozpoczął się kolejny okres określany nad Dunajem mianem „bús Magyarország” - znanej w dziejach węgierskiej odmiany rosyjskiej smuty. A czasy rozchwiania systemu wartości, smutku, bezradności, poczucia klęski i poniżenia prowadzą do zapaści psychicznej i moralnej ${ }^{46}$. Bardzo trafnie opisuje to zjawisko cytowany już K. Varga pisząc: „To prawda, Polacy są niebywale przywiązani do swoich traum narodowych, ale z Węgrami w tej konkurencji nie mają chyba jednak szans. Bez przyjęcia do wiadomości, że traktat pokojowy w Trianon z roku 1920 (na mocy, którego Węgry straciły dwie trzecie powierzchni i kilka milionów obywateli) do dziś wpływa na węgierską politykę, nie sposób zrozumieć wyborczego sukcesu V. Orbána. Można wręcz powiedzieć, że dwie ulubione dyscypliny Węgrów to piłka wodna i trauma narodowa" ${ }^{\text {"47 }}$. Węgrzy przodują na świecie pod względem ilości samobójstw w przeliczeniu na liczbę mieszkańców oraz zachorowań na choroby serca i nowotworowe, podczas gdy zamykają europejską stawkę w statystykach przeciętnej oczekiwanej długości życia. Nawet bajki węgierskie cechują się niespotykanym na świecie realizmem, gdyż ich najczęstsze zakończenie brzmi ,żyli długo i szczę́liwie... aż do śmierci”. „Pierwsze przeprowadzone na świecie badania nad ilością śmierci popełnianych na własne życzenie ujawniły, że w przypadku Węgrów aż 46 zgonów na każde 100000 to wynik samobójstwa, co stanowiło absolutny rekord światowy. Węgrzy uwielbiają też się nad sobą użalać. Oczywiście, gdy coś bardzo nie idzie po ich myśli, natychmiast zaczynają wspominać o samobójstwie, ale w większości wypadków kończy się na żalach i prawie jawnych prośbach o współczucie. Madziarowie świat widzą przede wszystkim w ciemnych barwach, we wszystkich wydarzeniach dopatrują się negatywnych konsekwencji, a czasem ich smutek jest tak wszechogarniający, że nawet przebywając $w$ ich towarzystwie i wysłuchując kolejnych utyskiwań na otaczający ich świat, ten pesymistyczny nastrój zaczyna się udzielać i nam ${ }^{48, "}$.

5. Polaryzacja społeczna i polityczna. W efekcie dziś każdy obywatel na Węgrzech - i to nie tylko ze względu na wymogi kampanii wyborczej - musi się jasno opowiedzieć: jesteś „,nasz” czy „,ich”, „,swój” czy „nie

\footnotetext{
46 B. Góralczyk, Wodzu prowadź. Tylko dokad, „Gazeta Wyborcza” z 24.04.2010.

47 K. Varga, O co gra Viktator, „Gazeta Wyborcza” z 8.01.2011.

48 Więcej na: http://www.budapeszt.infinity.waw.pl/joomla/index.php?option= com_content\&task=view\&id=880\&Itemid=27 z 15.12.2012.
} 
swój”, ,,rodzimy” czy „obcy”, „,narodowy” czy „liberalny”, chrześcijański czy „niechrześcijański”, a więc jak chcą politycy Fideszu - komunistyczny, liberalny, pozbawiony wiary w ojczyznę i tym samym wyższych wartości.

6. Jakość klasy politycznej. Dzisiejszy kryzys na Węgrzech to efekt życia ponad stan, a także tchórzostwa polityków, którzy bali się powiedzieć rodakom, że jakieś wyrzeczenia są potrzebne. Mamy więc z jednej strony „,narodową” politykę Orbána, z drugiej zaś skompromitowanych socjaldemokratów, którzy tegoż Orbána do władzy wynieśli i zapewnili mu tak silny mandat społeczny. Brutalnie tłumione przez policję demonstracje zwolenników Fideszu przysporzyły mu jedynie popularności i wzmogły nienawiść do socjalistów i liberałów, którzy uparcie trwali przy Gyurcsányu. Ten kurczowo trzymał się władzy, pracując na sukces Orbána.

7. Kadaryzm. Zjawisko charakterystyczne dla węgierskiego społeczeństwa i występujące tu na dwa sposoby. Po pierwsze, jako idea unikania konfliktów społecznych. Po 1956 roku Kádár uważał, że w każdej sytuacji należy ich unikać, nawet za cenę złych decyzji. Druga pozostałością jest paternalistyczny etatyzm, myślenie: „niech wszyscy mają pracę, bezpłatne świadczenia lekarskie” itd. Ale równocześnie „to, że oszukuję na podatkach, to rzecz absolutnie naturalna, bo niby jakim prawem państwo chce mi zabrać to, co moje?"49. Taka postawa jest dość charakterystyczna dla sporej części społeczeństwa. Podziela ją węgierska elita polityczna. Węgierski historyk Csaba G. Kiss w 2006 r. tłumaczył to w ten sposób: „W naszym kraju żyje bardzo wielu niezamożnych ludzi, którzy nie orientują się w polityce, żyją wciąż w epoce kadarowskiej. Tak, to, co dzisiaj jest na Węgrzech, to neokadaryzm. Media i społeczeństwo są manipulowane przez rząd. Ludzie żyją zaś w złudnym przeświadczeniu, że to, co się teraz dzieje z gospodarką węgierską - ogromny, największy w Unii deficyt budżetowy, który wynosi ponad 10 proc. PKB - to tylko przejściowe trudności. Nie chcą stracić poczucia złudnego dobrobytu" ${ }^{\prime 50}$.

Zastanawiając się nad przyszłymi losami Węgier można rozważyć dwa scenariusze. Pierwszy to kierunek, ,grecki” i trwanie w marazmie

49 Więcej na temat kadaryzmu w: M. Koźmiński, Odmiany i oblicza komunizmu. Wegrzy, Polacy i inni, Warszawa 2007.

50 J. Pawlicki w rozmowie z C. G. Kisem, Na Wegrzech jak za Kadara, „Gazeta Wyborcza" z 23.09.2006. 
i kryzysie gospodarczym, prowadzącym do powolnego bankructwa kraju, anarchii i dojścia do władzy ugrupowań skrajnie prawicowych. Drugi związany jest z sukcesem reform podejmowanych przez rząd Fideszu i wyrwaniem się Węgier ze spirali długu. W efekcie kluczowe dla dalszych losów Węgier będą decyzje podejmowane przez samego Orbána, czy zwycięży Orbán wizjoner i doktryner, który twierdzi, iż znalazł własny sposób na reformowanie gospodarki, a ze swojej antyeuropejskiej polityki uczynił nienegocjowalny dogmat, czy Orbán pragmatyk, prowadzący swą ,narodową” politykę na potrzeby wyborów, z drugiej jednak strony współpracujący z instytucjami politycznymi i ekonomicznymi. Polityk, który zdał sobie sprawę, że nie można uzdrowić gospodarki konfliktując się z Unią Europejską i światem finansów.

W tych rozważaniach należy wziąć pod uwagę również możliwość, iż to Orbán ma częściowo rację krytykując socjalny charakter Unii Europejskiej, jej prawodawstwo i perspektywy rozwoju. Wszak do Orbána negatywnie odnoszą się przede wszystkim, politycy i intelektualiści, którym bliżej do lewej strony sceny politycznej. Również niektórzy niezależni ekonomiści oceniają jego plan gospodarczy, a przynajmniej niektóre jego elementy, pozytywnie. C. G. Kiss przekonuje nawet, że: „Tworzenie wroga [Orbána - przyp. red.] jest więc raczej potrzebne Unii, nie Węrom. Orbán jest niezbędny jako chłopiec do bicia, przy którym Zachód zapomina o własnych problemach i wprowadza się w dobre samopoczucie" $"$. Problem tylko w tym, iż ten chłopiec do bicia zarówno wcześniej, jak i rządząc teraz po raz drugi, realnie nie zrobił prawie nic, aby wydobyć Węgry z zapaści i wyzwolić się z piętna Trianon. $\mathrm{W}$ wielu innych krajach europejskich to się jednak udało.

W efekcie najbardziej prawdopodobny wydaje się równie niebezpieczny dla Węgier wariant pośredni, czyli utrzymywanie się Orbána u władzy, ale bez przełomu politycznego i gospodarczego. Będzie to najprawdopodobniej trwanie od jednego kryzysu gospodarczego do kolejnego, przerywane prężeniem muskułów raz przez władze węgierskie, raz przez Komisję Europejską i MFW. Kierownictwo Fideszu nie jest ksenofobiczne, rasistowskie czy antysemickie. Jest cyniczne - jeśli okaże się, że to jedyna droga do zwycięstwa - obierze ją. Orbán musi zdać sobie jednak sprawę, że jeśli w najbliższym czasie nie da Węgrom jakie-

51 D. Kałan w rozmowie C. G. Kissem, Dlaczego popieram Orbana, „Gazeta Wyborcza" z 7.07.2011. 
goś namacalnego i odczuwalnego sukcesu gospodarczego, sama narodowa retoryka nie wystarczy i szybko również on, podobnie jak lewica, może znaleźć się na marginesie życia politycznego.

Któregoś dnia wyborcy Fideszu zorientują się, że poza deklaracjami, z polityki tej partii nic nie wynika, ich sytuacja materialna jest bardzo zła i oddadzą swój głos na Jobbik ${ }^{52}$ partię jeszcze bardziej radykalną w swych poglądach. Partię, która nie tylko instrumentalnie wykorzystuje hasła ksenofobiczne czy rasistowskie, ale naprawdę w nie wierzy i na nich buduje swoją tożsamość polityczną. Ugrupowanie, które być może nie poprawi ich sytuacji materialnej, ale w swej skrajnej retoryce nie pójdzie na żadne ustępstwa. Takie rozwiązanie, w kraju pogrążonym w permanentnym kryzysie gospodarczym, skonfliktowanym z sąsiadami, byłoby już prawdziwym zagrożeniem dla Europy, dużo większym niż dzisiejsza retoryka Orbána.

\section{Hungary in the period from 1990-2011. \\ Political and economic sources of the crisis}

\section{Summary}

The paper attempts to answer the question of why Hungary, a country that many Western politicians praised as an exemplary model of transformation until recently, has become a European outsider, a country whose economic situation is barely better than that of Greece going bankrupt. Both political and socio-economic reasons for the crisis are indicated. The former concern the long years of living beyond their means and the cowardice of the politicians, afraid to tell their fellow citizens that

52 Jobbik - Ruch na rzecz Lepszych Węgier. Jobbik powstał w 2003 roku, gdy program Fideszu stał się dla części jego członków zbyt mało radykalny. Fidesz nie upominał się twardo o utracone przez Węgry Górną Słowację i Siedmiogród, nie dbał wystarczająco o prawa zamieszkałej tam węgierskiej mniejszości, niedostatecznie krytykował opanowaną ich zdaniem przez Węgierskich Żydów partię Wolnych Demokratów, która zdradziła reformujące się Węgry i wsparła postkomunę. A przy tym wszystkim Fidesz tolerował gejów. Te wszystkie zaniedbania uwzględniał program Jobbiku. Wybory 2010 roku przyniosły tej partii spektakularny sukces. Jobbik po raz pierwszy wszedł do węgierskiego parlamentu, poprawiając swój wynik sprzed czterech lat o ponad 14 punktów procentowych. Zdobył 16,67 proc., stając się trzecią polityczną siłą na Węgrzech. Jak pokazały ostatnie sondaże w listopadzie $2011 \mathrm{r}$. już prawie 20 proc. Węgrów deklarowało chęć głosowania na skrajną prawicę. Tym samym Jobbik stał się drugą siłą pod względem poparcia na węgierskiej scenie politycznej, wyprzedzając rządzących do niedawna socjalistów. 
sacrifices are necessary. The economic sources of the crisis concern the procrastination and non-completion of reforms that could have made Hungary a more competitive economy. The third group of factors that contributed to the crisis was related to the condition of Hungarian society, a society that in the mid-nineteen-nineties entered another period described as bús Magyarország, a Hungarian version of Russian smuta (trouble). A period of an upset system of values, sadness, helplessness, a sense of defeat and humiliation have led to mental and moral collapse. All this may result in Hungary's recovery from the crisis being a very difficult and prolonged process. 
